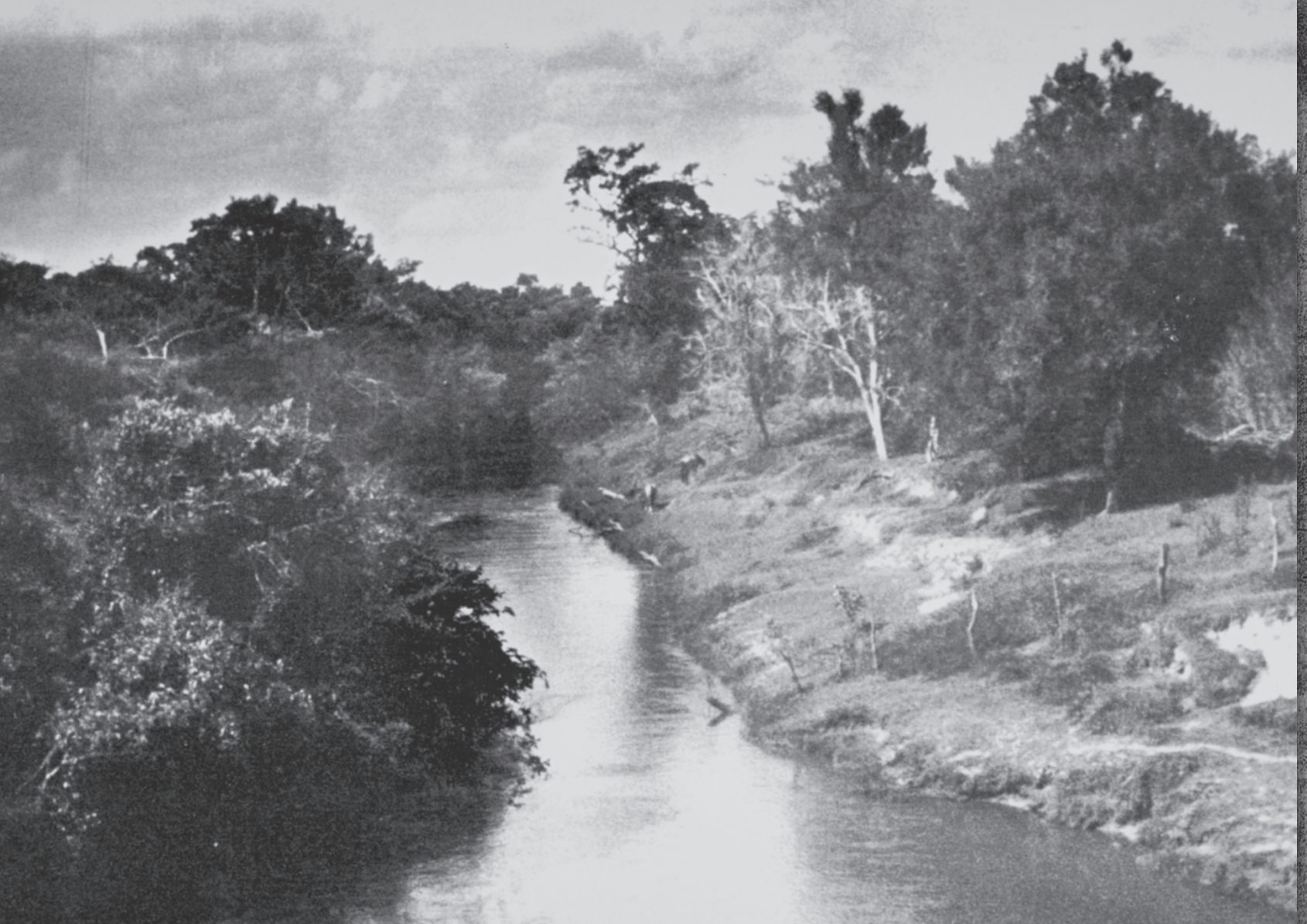

\title{
Antonio Candido e o mundo caipira
}

Todas as fotos desta seção pertencem ao Arquivo do Instituto de Estudos Brasileiros USP - Fundo Antonio Candido de Mello e Souza 

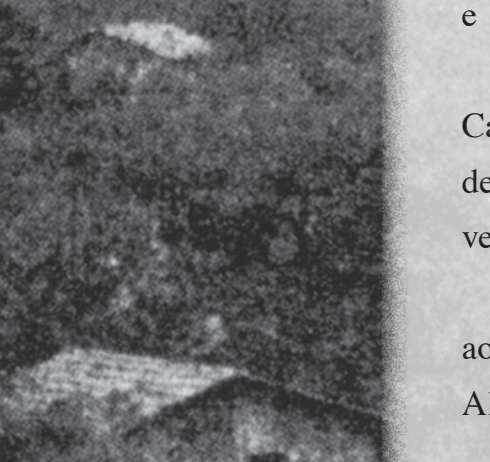

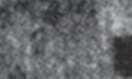
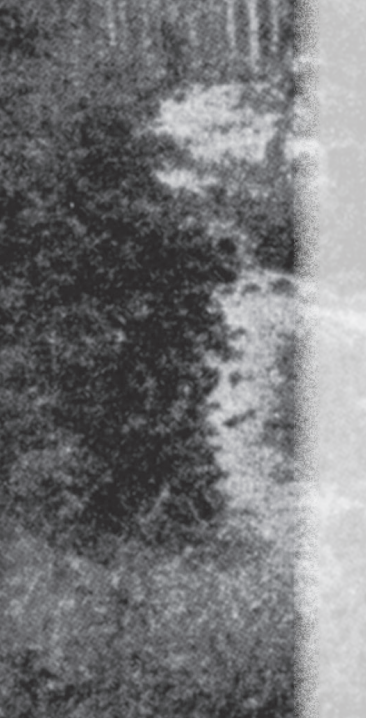

A

presentamos a seguir uma seleção de textos pouco divulgados de

Antonio Candido versando temas caipiras, começando por "Opinião e classes sociais em Tietê", de 1947.

Quase dez anos depois, em 1956, Antonio Candido publicaria "Possíveis raízes indígenas de uma dança popular", em que pela primeira vez dedica sua atenção ao cururu.

O texto seguinte, "Caipiradas", é introdução aos discos Caipira: raízes e frutos, iniciativa de Aluizio Falcão e datados de 1980.

Completam o dossiê dois textos meus. O primeiro, "Na carrera do Divino", analisa um espetáculo teatral dirigido por Paulo Betti, baseado em Os parceiros do Rio Bonito. O segundo, "A cultura caipira", registra o lançamento da $11^{\mathrm{a}}$ edição desse livro, um clássico da sociologia rural que gerou numerosa descendência.

Tudo isso serve para contextualizar a peça central deste dossiê, que é a entrevista inédita concedida por Antonio Candido a Paulo Betti, muito mais tarde, em 2007, a propósito do cururu.

Walnice Nogueira Galvão
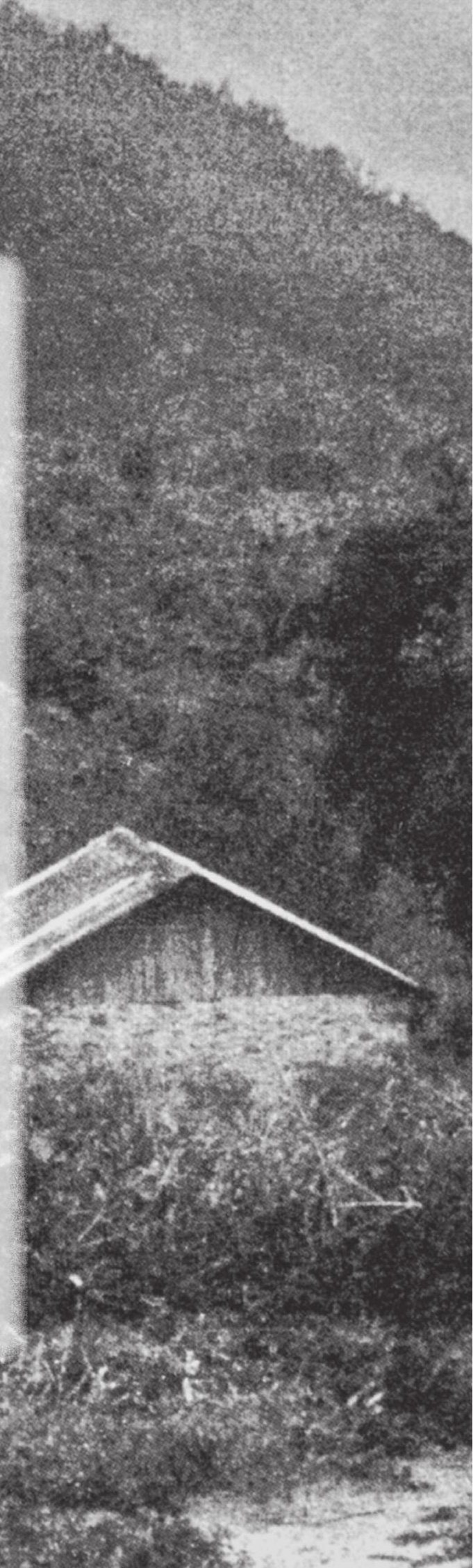